he seldom failed to find some new angle leading to clearer vision. Being shy and reserved, he made comparatively few friends; but those whom he had, found him a most entertaining companion. They appreciated also his extreme conscientiousness and sense of duty. He was a man of strong convictions, which he urged with pugnacity tempered by a delightful sense of humour.

No account of Robb would be complete without reference to his gift for writing topical verse and parody. He wrote many of the songs sung at the annual dinners of the Cavendish Society. His feat of adapting Maxwell's equations as the chorus of a song must have earned the gratitude of many who, like the present writer, could never remember them otherwise.

Robb was a thorough Irishman, in voice, appearance and sentiment. Though his home and family connexions were in Belfast, his sympathies were generally with the South. After passing through Queen's College, Belfast, he became a research student at St. John's College, Cambridge; he afterwards studied at Göttingen, where he took a Ph.D. degree. Being possessed of independent means, he never sought a post; but his habit was to spend most of term-time in Cambridge, living very quietly in lodgings, seeing a few old friends, and mainly occupied with mathematical research.

When the Great War came, Robb voluntarily undertook chemical work in connexion with the supply of medical drugs. But after some time his suspicions were aroused, and being unable to obtain an assurance that his products were not intended for the production of poison gas, he resigned. Not to be deterred from medical service, he learned to drive a motorcar and served as an ambulance-driver in France. In later years he joined Emmanuel College and was made a member of the High Table. Sometimes by invitation of the Faculty Board of Mathematics he gave a course of lectures on his theory. He was elected to the Royal Society in 1921.

This quiet academic life was rudely broken about five years ago, when Robb was called by circumstances to assume the management of his family business-an important firm in Belfast. Through a series of deaths of near relations, he was left almost the sole adult representative of his family, and it depended on him to keep things going in the interests of the next generation. For him it was a most uncongenial change ; but he appears to have adapted himself to it successfully. He retained his rooms in Cambridge, hoping to find opportunity to return; but his visits have been rare. The new edition of his book, which contains considerable changes, is evidence that he remained active in mathematical research up to his death.

A. S. E.

\section{Sir Henry Hall, I.S.O.}

Is is with great regret that we have to record the death of Sir Henry Hall, who died at Brookside, Chester, on December 8, at the ripe age of ninety years; he was born, therefore, in 1846, and was the youngest son of Mr. John Hall, of Sedgefield, Co. Durham. He served his time at the old Haswell Colliery Co., Durham, and got an appointment in the Swansea district in 1873. About 1875 he was appointed inspector of mines in that district, and was afterwards transferred to Lancashire, and was in addition given the care of North Wales when districts were reorganized a few years later (about 1910).

According to his own account, an accident at Wynnstay Colliery, North Wales, about the year 1874, first directed Sir Henry's attention to the danger of coal dust, and in 1890 he was appointed to experiment on the subject by the Royal Commission, which sat under the Right Hon. Joseph Chamberlain, M.P., as chairman, and consisted of a number of men well versed in explosions and mining, who altogether examined thirty-nine witnesses. According to his own statement, three different collieries were experimented on, in shafts ranging from $50 \mathrm{yd}$. to $200 \mathrm{yd}$. deep, and in a gallery some $45 \mathrm{yd}$. deep, using dust from the various districts of the country and no firedamp. It was not a new idea of Mr. (as he then was) Henry Hall's, the original idea being due to Faraday and $\mathrm{Mr}$. Lyell, according to $\mathrm{Mr}$. Godfrey Lushington (in Answer 66) in 1844. It was then revived by Mr. William Galloway and Messrs. W. N. and J. B. Atkinson, in which an explosion in a hopper, where no firedamp was present, was cited.

Mr. Henry Hall's results were accepted by the industry, but his remedies for this state of affairs, namely, watering and the use of high explosives (not gunpowder), were not followed up, because watering was not a complete remedy and often produced 'creep', and Sir William Edward Garforth's further experiment on the use of stone dust, finely divided, has been accepted by the industry in general and is now confirmed by legislation. The remedial suggestion decidedly advocated by Mr. Henry Hall was the use of the safety lamp, according to Mr. J. B. Atkinson, which has since been made compulsory by legislation.

For this service and his numerous papers read before the North of England Institute of Mining and Mechanical Engineers, and before the Institution of Mining Engineers-these among other services to the mining industry-Hall was given the medal of the Institution of Mining Engineers in 1928, whilst he was awarded the Imperial Service Order, and afterwards received the honour of knighthood. His death removes a man whose name is a household word in the mining industry, and who has ever, even after his retirement from the inspectorship, taken the keenest possible interest in the industry.

\section{Dr. E. S. Cobbold}

THE ranks of the amateur geologists have been seriously thinned by the death of Edgar Sterling Cobbold on November 20, in his eighty-sixth year. The son of a surgeon who was greatly interested in natural history, he studied engineering at the Owens College and, after some fifteen years' practice, retired to Church Stretton in 1886. Here he at once threw 
himself into the study of the district, taking an active part in the proceedings of local natural history societies, and contributing extensively on archæology and geology to both scientific and popular guides to the area.

Cobbold's first contribution to geology here was the description of a Silurian outlier of much tectonic significance under Caer Caradoc. He soon came under the spell of the thoroughness and accuracy of Charles Lapworth's work, and became infected with his enthusiasm for the ancient rocks. Lapworth's discovery of the Olenellus fauna in Shropshire, and Groom's find of Paradoxides, having demonstrated the existence of Lower and Middle Cambrian rocks in the Stretton and Wrekin areas, Cobbold proceeded to collect from these rocks inch by inch. His reward was the discovery of many forms new to Great Britain and to science. He described a dozen new genera and more than a hundred new species from them, and was able to divide the Lower Cambrian into eleven, and the Middle into nine divisions, mostly definite life zones.

Thus Cobbold made his area the type-section for Britain, correlated the rocks with those of America and the Continent, and demonstrated the existence of breaks in the sequence caused by earth movements.
He became our leading authority on Cambrian faunas, and was called in by the Geological Survey to determine the fossils collected by himself and others from the considerable Cambrian area between the Wrekin and Charlton Hill. His type-fossils have been lodged in the British Museum, the Geological Survey Museum, or the Sedgwick Museum.

The work that Cobbold accomplished with such conspicuous success could only have been carried out by one living on the spot, with abundant leisure and the knack of using it effectively, with remarkable energy, industry, devotion, and perseverance, with wide knowledge of his subject and its literature in many languages, and with the hand and eye of an artist.

W. W. W.

We regret to announce the following deaths :

Mr. Thomas Crook, O.B.E., since 1928 principal of the Mineral Resources Department, Imperial Institute, London, on January 6.

Mr. P. A. Ellis Richards, president of the Society of Public Analysts in 1922-23, aged sixty-eight years.

Sir David Semple, founder and first director (1900-5), of the Pasteur Institute of India on January 7, aged eighty years.

\section{News and Views}

Prof. E. B. Bailey, F.R.S.

THE Lord President of the Council has appointed Prof. E. B. Bailey, professor of geology in the University of Glasgow, to be director of the Geological Survey of Great Britain and of the Museum of Practical Geology, a post rendered vacant by the untimely death last year of Dr. Bernard Smith. Prof. Bailey previously served on the staff of the Survey for some twenty-seven years. After a distinguished career at Cambridge, where he gained the Harkness scholarship in geology, in 1902 he was appointed geologist to the Geological Survey of Scotland, with headquarters in Edinburgh, where he remained until 1929. During the years he served in Scotland, Prof. Bailey made a special study of the tectonics of the Dalvadian schists, a subject in which he became an acknowledged leader. He also took an important part in the survey of the tertiary igneous rocks in Mull, and edited the Survey memoir on this area. Other duties carried out during his years on the Survey included much work on the Carboniferous rocks in the Midland Valley of Scotland. His experience was further widened by visits abroad from time to time. Prof. Bailey's Survey career was interrupted by the Great War, during which he saw much service in France with the Royal Artillery, receiving the Military Cross, the Legion d'Honneur and the Croix de Guerre as rewards for distinguished services. His enthusiasm for geology was such that he even found time to publish papers on this subject during the time he was engaged on military service.
IN 1929, Prof. Bailey resigned from the post of district-director in Scotland, to take up his appointment to the chair of geology in Glasgow. During his tenure of this post, he has continued his researches into Highland tectonics, and has also developed the application of current-and graded-bedding to the question of the age of the Highland schists. Among the academic and other distinctions received by Prof. Bailey may be mentioned the following : from the Geological Society of London, in 1923 the Bigsby Medal, and in 1935 the Murchison Medal ; in 1928, president of Section C (Geology) of the British Association; in 1930, elected fellow of the Royal Society ; in 1936, awarded the honorary degree of D.Sc. by Harvard University at its tercentenary celebration. The results of the official work carried out by Prof. Bailey, and of his private researches, are contained in numerous memoirs of the Geological Survey, and in the publications of various learned societies. $\mathrm{He}$ is also the author of "Tectonic Essays : Mainly Alpine".

\section{The Piltdown Jaw}

IN another column of this issue of NATURE (see p. 120) reference is made to the reaffirmation by Prof. F. Weidenreich of the Cenozoic Research Laboratory, Peiping, of the orang-like character of the Piltdown jaw, which he relegates to the group orang-chimpanzee-gorilla, standing outside the line of human descent. In this connexion attention may be directed to another attack on the human character 